\title{
ANALISIS PENGARUH PENERIMAAN PAJAK HOTEL, PAJAK REKLAME DAN PAJAK PARKIR TERHADAP PENDAPATAN ASLI DAERAH (PAD) \\ (STUDI EMPIRIS PADA KABUPATEN/KOTA DI PROVINSI JAWA TENGAH TAHUN 2009-2016)
}

\author{
Tuti Priyanti \\ tutilaatahzan@gmail.com \\ Mahasiswa Program Studi S1 Akuntansi Fakultas Ekonomi \\ Universitas Muhammadiyah Semarang \\ Ayu Noviani Hanum \\ ayu_hanum@yahoo.com \\ Fakultas Ekonomi Universitas Muhammadiyah Semarang \\ Ery Wibowo \\ ery@unimus.ac.id \\ Fakultas Ekonomi Universitas Muhammadiyah Semarang \\ Riwayat Artikel: dikirim Oktober 2018, diterima September 2018, diterbitkan September 2018

\section{ABSTRAK}

This research is entitled Analysis of Hotel Tax Influence, Advertisement Tax and Parking Tax on Regional Original Income. The purpose of this study was to determine the effect of hotel tax, advertisement tax and parking tax on local revenue in Central Java Province in 2009-2016.

The data used are Regional Original Revenue, Hotel Tax, Advertising Tax and Parking Tax for Surakarta City, Semarang City, Pati Regency, Klaten Regency and Banyumas Regency in 2009-2016 to examine the effect of hotel tax, advertisement tax and parking tax on local revenue. The analysis technique used is Multiple Regression Analysis.

The results showed that Hotel Tax has a partial effect on Regional Original Income with a significant value of 0.009, Advertisement Tax has no partial effect on Regional Original Income with a significant value of 0.349 and parking tax does not have a partial effect on Regional Original Income with a significant value of 0.456. While the hotel tax, advertisement tax and parking tax simultaneously affect local revenue.

Keywords: Hotel Tax, Advertisement Tax, Parking Tax, and Regional Original Income 
PENDAHULUAN

\subsection{Latar belakang}

Pemerintahan Daerah adalah
penyeleng- garaan urusan
pemerintahan oleh pemerintah daerah
dan dewan perwakilan rakyat daerah
menurut asas otonomi dan tugas
pembantuan dengan prinsip otonomi
seluas-luasnya dalam sistem dan
prinsip Negara Kesatuan Republik
Indonesia sebagaimana dimaksud
dalam Undang-Undang Dasar Negara
Republik Indonesia Tahun 1945.
Pemerintah daerah berhak dan berkewajiban untuk mengelola rumah tangganya sendiri. Salah satunya dengan pengefektifan Anggaran Pendapatan dan Belanja Daerah. Di dalam ABPD terdapat Pendapatan Asli Daerah. Besarnya kontribusi PAD dalam APBD merupakan ukuran keberhasilan penyelenggaraan pembangunan,

pelayanan, peningka $-\tan$ kesejahteraan masyarakat (Faisal, 2010).

Berdasarkan data Provinsi Jawa Tengah Dalam Angka tahun 2017, realisasi PAD pada tahun anggaran 2016 terhimpun sebesar 19,63 trilyun rupiah naik 16,6 persen dibandingkan tahun anggaran 2015. Pendapatan Asli Daerah terdiri dari pajak daerah, retribusi daerah, hasil pengelolaan kekayaan daerah dan lain-lain pendapatan daerah yang sah . Kontribusi pajak daerah di Provinsi Jawa Tengah adalah sebanyak 9, 67 trilyun atau sebanyak 49,27\% dari total pendapatan asli daerah pada tahun 2016.

Penelitian ini akan menggunakan variabel pajak daerah sebagai variabel independen. Dari beberapa sumber pajak daerah yang ada, penelitian ini hanya menggunakan variabel yang terjadi ketidakkonsistenan pada peneliti-peneliti sebelumnya.
Pengaruh variabel pajak pajak hotel terhadap pendapatan asli daerah disebabkan oleh semakin meningkatnya tempat penginapan/hotel di Provinsi Jawa Tenggah (Riskhi, 2017). Dengan asumsi tersebut, maka pendapatan dari akomodasi tersebut meningkat sehingga pendapatan pajak hotel juga harusnya meningkat. Namun pada kenyataannya masih ada hasil dari para peneliti yang menyatakan bahwa pajak hotel tidak berpengaruh pada pendapatan asli daerah.

Obyek pajak reklame akan tumbuh seiring dengan pertumbuhan perusahaan atau industri (Nurmayasari, 2010). Berdasarkan data dari Badan Pusat Statistik Provinsi Jawa Tengah, jumlah perusahaan pada tahun 2014 sebanyak 3.666. Jumlah ini meningkat pada tahun 2015 yaitu sebanyak 4.378 perusahaan. Pemanfaatan penerimaan pendapatan daerah pada sektor pajak reklame ini dapat dimanfaatkan sebaik mungkin. yâng terdaftar pada Kepolisian Daerah Jawa Tengah tercatat sebanyak 15,07 juta unit pada tahun 2016, jumlah ini naik 0,31 persen dibanding tahun 2015 yaitu sebanyak 15,11 juta unit . Kendaraan bermotor terbanyak adalah jenis Sepeda motor yang mencapai 13,24 juta unit. Secara otomatis kebutuhan akan lahan parkir sangatlah besar seiring dengan makin banyaknya jumlah kendaraan. Parkir adalah keadaan tidak bergerak suatu kendaraan yang tidak bersifat sementara. Fenomena yang sering kita temui di lingkungan sekitar yaitu banyaknya kendaraan yang parkir entah itu di lahan khusus parkir maupun parkir liar.

Pajak parkir sendiri berada di urutan 8 dalam memberikan pemasukan terhadap Pajak Daerah. Ini menjadi perhatian khusus bagi pemerintah daerah di Jawa Tengah 
untuk meningkatkan pendapatan asli daerah (Fadillah, 2015). Maka dari itu, pajak parkir ini perlu dibuktikan kembali sudah efektifkah pengelolaan pajak parkir di wilayah Jawa Tengah karena melihat potensinya yang lumayan bisa meningkatkan pajak daerah.

Berdasarkan data dan fenomena diatas, maka penelitian ini bertujuan untuk membuktikan pengaruh pajak daerah khususnya pajak hotel, pajak reklame dan pajak parkir terhadap PAD Provinsi Jawa Tengah. Maka dari itu penelitian ini berjudul Analisis Pengaruh Pajak Hotel, Pajak Reklame dan Pajak Parkir Terhadap Pendapatan Asli Daerah (Studi Empiris Pada Kabupaten/Kota di Provinsi Jawa Tengah Tahun 20092016).

\subsection{Rumusan masalah}

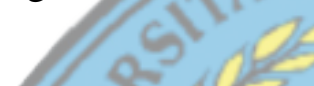

Berdasarkan uraian latar belakang penelitian yang telah diungkapkan sebelumnya, dirumuskan permasalahan penelitian sebagai berikut :

a. Bagaimana pengaruh pajak hotel, pajak reklame, dan pajak parkir secara parsial terhadap Pendapatan Asli Daerah (PAD) Kabupaten/Kota di Provinsi Jawa Tengah tahun 2009-2016?

b. Bagaimana pengaruh pajak hotel, pajak reklame, dan pajak parkir secara simultan terhadap Pendapatan Asli Daerah (PAD) Kabupaten/Kota di Provinsi Jawa Tengah tahun 2009-2016?

1.3. Tujuan Penelitian

Tujuan dilakukannya penelitian ini adalah:

a. Untuk menganalisis pengaruh pajak hotel, pajak reklame dan pajak parkir secara parsial terhadap Pendapatan Asli Daerah (PAD) Kabupaten/Kota di
Provinsi Jawa Tengah tahun 2009-2016?

b. Untuk menganalisis pengaruh pajak hotel, reklame, dan pajak parkir secara simultan terhadap Pendapatan Asli Daerah (PAD) Kabupaten/Kota di Provinsi Jawa Tengah tahun 2009-2016?

\section{LANDASAN TEORI}

\subsection{Teori Stewardship}

Grand theory dalam penelitian ini adalah menggunakan Stewardship Theory. Teori Stewardship menjelaskan mengenai situasi manajemen tidaklah termotivasi oleh tujuan-tujuan individual melainkan lebih ditujukan pada sasaran hasil utama mereka untuk kepentingan organisasi (Donaldson, 1989 dan Davis, 1991).

2.2. Pengertian Pendapatan Asli Daerah Pendapatan Asli Daerah (PAD) adalah penerimaan yang diperoleh daerah dari sumber-sumber dalam wilayah sendiri yang dipungut berdasarkan peraturan daerah sesuai dengan perundang-undangan yang berlaku (Halim: 2001). Tujuan PAD yang termuat di dalam UndangUndang Republik Indonesia Nomor 23 Tahun 2014 Tentang Pemerintahan Daerah, memberikan kewenangan kepada Pemerintah Daerah untuk mendanai otonomi daerah sesuai dengan potensi daerah sebagai perwujudan desentralisasi. Semakin tinggi PAD yang dimiliki oleh daerah maka akan semakin tinggi kemampuan daerah untuk melaksanakan desentralisasi.

2.3. Pengertian Pajak

Prof. Dr. Soemitro, S.H dalam bukunya Mardiasmo (2016:3) menyatakan, Pajak adalah iuran rakyat kepada kas negara berdasarkan undang-undang (yang dapat dipaksakan) dengan tiada mendapat jasa timbal (kontraprestasi) yang langsung dapat ditunjukkan dan yang 
digunakan untuk membayar pengeluaran umum.

2.4. Pengertian Pajak Daerah

Undang-udang No.28 Tahun 2009 Tentang Pajak Daerah dan Retribusi Daerah menguraikan bahwa Pajak Daerah, yang selanjutnya disebut Pajak, adalah kontribusi wajib kepada Daerah yang terutang oleh orang pribadi atau badan yang bersifat memaksa berdasarkan UndangUndang, dengan tidak mendapatkan imbalan secara langsung dan digunakan untuk keperluan Daerah bagi sebesar-besarnya kemakmuran rakyat.

2.5. Pengertian Pajak Hotel

Pajak Hotel adalah pajak atas pelayanan yang disediakan oleh hotel (Undang Undang Nomor 28 Tahun 2009). Sedangkan hotel adalah fasilitas penyedia jasa penginapan /peristirahatan termasuk jasa terkait lainnya dengan dipungut bayaran, yang mencakup juga motel, losmen, gubuk pariwisata, wisma pariwisata, pesanggrahan, rumah penginapan dan sejenisnya, serta rumah kos dengan jumlah kamar lebih dari 10 (sepuluh).

2.6. Pajak Reklame

Menurut Peraturan Daerah Nomor 12 Tahun 2011, tentang Pajak Reklame, Reklame adalah benda, alat, perbuatan, atau media yang bentuk dan corak ragamnya dirancang untuk tujuan komersial memperkenalkan, menganjurkan, mempro- mosikan, atau untuk menarik perhatian umum terhadap barang , jasa, orang, atau badan, yang dapat dilihat, dibaca, didengar dirasakan dan/atau dinikmati oleh umum.

\subsection{Pajak Parkir}

Pajak parkir yaitu pajak yang dikenakan atas penyelenggarakan tempat parkir diluar badan, baik yang disediakan berkaitan dengan pokok usaha maupun yang disediakan sebagai suatu usaha, termasuk penyediaan tempat penitipan kendaraan bermotor dan garansi kendaraan bermotor yang memungut bayaran (Samudra, 2015).

2.8. Kerangka Pemikiran

Gambar 2.1

Hubungan antar Variabel Y dan X

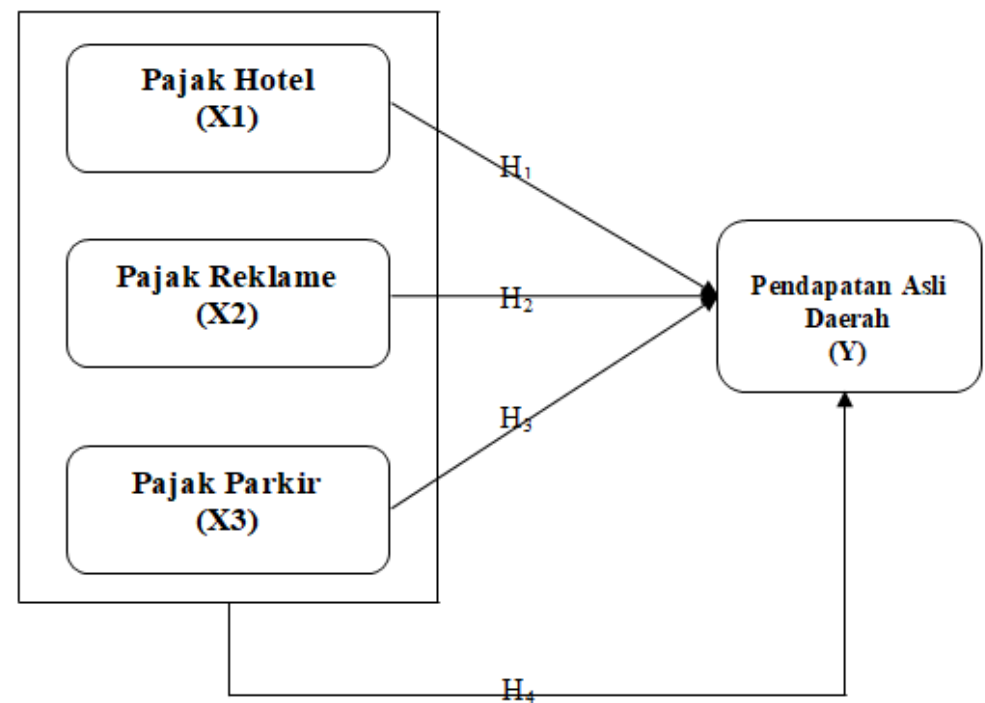

\section{HIPOTESIS}

ANALISIS PENGARUH PENERIMAAN...

Tuti Priyanti, Ayu Noviani Hanum, Ery Wibowo 
H1: Pajak Hotel secara parsial berpengaruh positif dan signifikan terhadap Pendapatan Asli Daerah Kabupaten/Kota di Provinsi Jawa Tengah.

H2: Pajak Reklame secara parsial berpengaruh positif dan signifikan terhadap Pendapatan Asli Daerah Kabupaten/Kota di Provinsi Jawa Tengah.

\section{METODE PENELITIAN}

\subsection{Sampel}

Pengambilan sampel dalam penelitian ini yakni menggunakan teknik purposive sampling. Data file yang di seleksi adalah file Jawa Tengah Dalam Angka yang di dapat dalam website Badan Pusat Statistika dari tahun 2010-2017.

3.2. Sumber

Jenis dan sumber data yang digunakan dalam penelitian ini adalah
H3: Pajak Parkir secara parsial berpengaruh positif dan signifikan terhadap Pendapatan Asli Daerah Kabupaten/Kota di Provinsi Jawa Tengah.

H4: Pajak Hotel, Pajak Reklame dan Pajak Parkir secara simultan berpengaruh signifikan terhadap Pendapatan Asli Daerah Kabupaten/Kota di Provinsi Jawa Tengah.

data sekunder. Metode pengambilan data adalah dengan seleksi data di website Badan Pusat Statistika pada bagian Publikasi dan mengambil data langsung ke Badan Keuangan Daerah masing-masing daerah sampel

3.3.Model Analisis Data

Metode analisisnya ialah Analisis Regresi Berganda

$Y=a+b_{1} X_{1}+b_{2} X_{2}+b_{3} X_{3}+\varepsilon$

a. Uji Statistik Deskriptif

b. Uji Asumsi Klasik

c. Uji Hipotesis Penelitian

\section{HASIL DAN PEMBAHASAN}

\subsection{Statistik Deskriptif}

Rata-rata dari data pajak hotel sejumlah $\mathrm{Rp}$ 12.938.646.694,00, nilai minimum dari data pajak hotel sejumlah Rp 127.591.750,00 yaitu pajak hotel dari Kabupaten Klaten tahun 2009, nilai maksimum dari pajak hotel sejumlah Rp 66.350.807.540,00 yaitu Kota Semarang tahun 2016. Sedangkan rata-rata dari data pajak reklame sejumlah Rp 6.378.003.336,00, nilai minimum dari pajak reklame sejumlah Rp 436.032.760,00 yaitu Kabupaten Pati tahun 2009, nilai maksimum dari data pajak reklame sejumlah $\quad \mathrm{Rp} \quad 29.368 .119 .634,00$ yaitu Kota Semarang tahun 2016. Untuk pajak parkir rata-rata datanya sejumlah Rp 1.774.630.644,00, nilai minimum dari data pajak parkir sejumlah Rp 16.500.240,00 yaitu Kabupaten Pati tahun 2009, nilai maksimum dari data pajak parkir adalah $\mathrm{Rp}$ 11.386.174.270,00 yaitu Kota Semarang tahun 2016. Ratarata dari data pendapatan asli daerah sejumlah Rp 321.066.328.287,00, nilai minimum dari data pendapatan asli daerah sejumlah Rp 54.398.522.276,00 yaitu Kabupaten Klaten tahun 2009, nilai maksimum dari data pendapatan asli daerah sejumlah Rp 1.337.270.317.040,00 yaitu Kota Semarang tahun 2016. 


\subsection{Asumsi Klasik}

a. Uji Normalitas

Gambar 4.2

\section{Uji Normalitas}

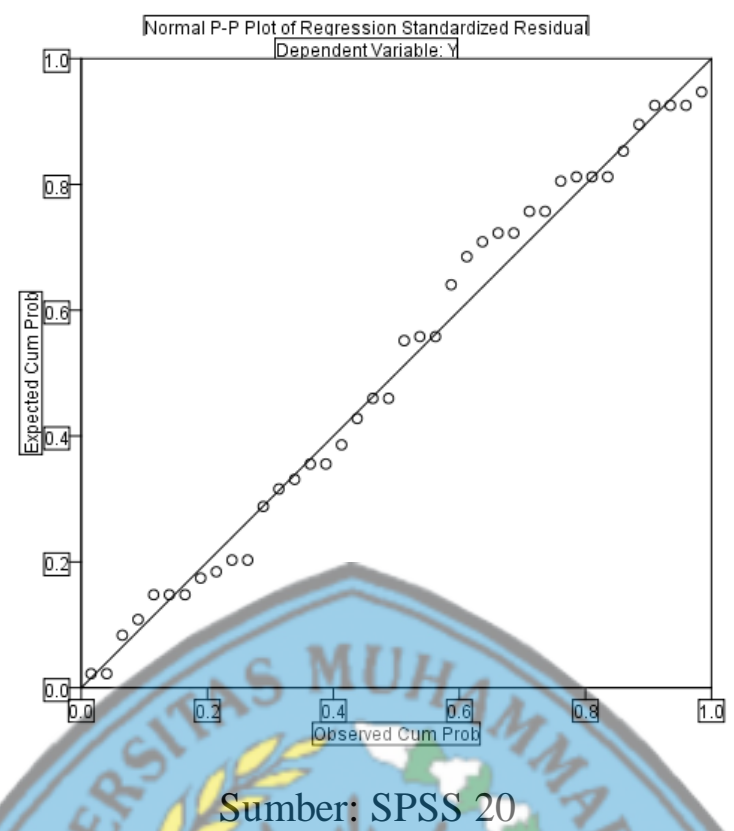

Menurut gambar di atas menyebutkan bahwa data tersebut terdistribusi normal.

b. Uji Multikolinearitas

\section{Tabel 4.3}

\section{Uji Multikolinearitas}

\begin{tabular}{|l|r|r|c|}
\hline \multicolumn{1}{|c|}{ Variabel } & Tolerance & VIF & \multicolumn{1}{c|}{ Kesimpulan } \\
\hline $\begin{array}{l}\text { X1 } \\
\text { (Pajak Hotel) }\end{array}$ & 0.276 & 3.622 & $\begin{array}{c}\text { Tidak terdapat } \\
\text { mutikolinearitas }\end{array}$ \\
\hline $\begin{array}{l}\text { X2 } \\
\text { (Pajak Reklame) }\end{array}$ & 0.114 & 8.810 & $\begin{array}{c}\text { Tidak terdapat } \\
\text { mutikolinearitas }\end{array}$ \\
\hline $\begin{array}{l}\text { X3 } \\
\text { (Pajak Parkir) }\end{array}$ & 0.118 & 8.462 & $\begin{array}{c}\text { Tidak terdapat } \\
\text { mutikolinearitas }\end{array}$ \\
\hline
\end{tabular}

Sumber data aplikasi SPSS 20.0

Nilai VIF di bawah 10 yang artinya tidak terjadi masalah multikolinearitas. 
c. Uji Autokolerasi

Tabel 4.4.

Uji Autokolerasi

\begin{tabular}{|l|r|}
\hline & \multicolumn{2}{|c|}{ Unstandardized Residual } \\
\hline Test Value $^{\mathrm{a}}$ & .00951 \\
\hline Cases < Test Value & 20 \\
\hline Cases >= Test Value & 20 \\
\hline Total Cases & 40 \\
\hline Number of Runs & 20 \\
\hline Z & -.160 \\
\hline $\begin{array}{l}\text { Asymp. Sig. (2- } \\
\text { tailed) }\end{array}$ & .873 \\
\hline
\end{tabular}

Sumber data aplikasi SPSS 20.0

Hasil penelitian ini menunjukkan dengan nilai Asymp. Sig. (2-tailed) bahwa data penelitian bebas dari sebesar 0.873 yang masalah autokorelasi, terbukti $\left(\mathrm{h}_{\mathrm{w}} / \mathrm{f}\right.$ artinya lebih besar dari 0.05 .

d. Uji Heterokedastisitas

Tabel4.5.

Uji Heteroskedastisitas

\begin{tabular}{|l|l|r|}
\hline \multirow{2}{*}{ Variabel } & \multicolumn{1}{|c|}{ Correlation } & \multicolumn{2}{c|}{$\begin{array}{c}\text { Unstandardized } \\
\text { Residual }\end{array}$} \\
\hline \multirow{4}{*}{ X1 } & Correlation Coefficient & -.043 \\
\cline { 2 - 4 } & Sig. (2-tailed) & .793 \\
\cline { 2 - 4 } & N & 40 \\
\hline \multirow{3}{*}{ X2 } & Correlation Coefficient & -.248 \\
\cline { 2 - 4 } & Sig. (2-tailed) & .123 \\
\cline { 2 - 4 } & N & 40 \\
\hline \multirow{3}{*}{ X3 } & Correlation Coefficient & -.217 \\
\cline { 2 - 4 } & Sig. (2-tailed) & .178 \\
\cline { 2 - 4 } & N & 40 \\
\hline
\end{tabular}

Sumber : Diolah oleh SPSS 20

Dari hasil SPSS 20 menunjukkan nilai signifikan dari ketiga variabel pada Unstandardized Residual. Angka tersebut lebih dari 0.05 yang artinya tidak terdapat masalah heteroskedastisitas pada model penelitian Ini. 
Tabel 4.6

Coefficients

\begin{tabular}{|c|c|c|c|c|c|c|}
\hline \multirow{2}{*}{\multicolumn{2}{|c|}{ Model }} & \multicolumn{2}{|c|}{$\begin{array}{l}\text { Unstandardized } \\
\text { Coefficients }\end{array}$} & \multirow{2}{*}{$\begin{array}{c}\text { Standardized } \\
\text { Coefficients }\end{array}$} & \multirow[t]{2}{*}{$\mathrm{T}$} & \multirow[t]{2}{*}{ Sig. } \\
\hline & & B & Std. Error & & & \\
\hline \multirow{4}{*}{1} & $($ Constant $)$ & 17.754 & 2.170 & & 8.180 & .000 \\
\hline & X1 & .275 & .099 & .628 & 2.780 & .009 \\
\hline & $\mathrm{X} 2$ & .220 & .232 & .335 & .950 & .349 \\
\hline & X3 & -.123 & .164 & -.260 & -.754 & .456 \\
\hline
\end{tabular}

Sumber data aplikasi SPSS 20.0

$$
\begin{gathered}
\mathrm{Y}=\alpha+\mathrm{b}_{1} \mathrm{X}_{1}+\mathrm{b}_{2} \mathrm{X}_{2}+\mathrm{b}_{3} \mathrm{X}_{3}+\varepsilon \\
\mathrm{Y}=17.754+0.275 \mathrm{X} 1+0.220 \mathrm{X} 2 \\
+(-0.123) \mathrm{X} 3+\varepsilon
\end{gathered}
$$

Penjelasan persamaan diatas sebagai berikut:

a. Nilai kostanta (a) sebesar 17.754 menunjukkan nilai positif jika pajak hotel, pajak reklame dan pajak parkir nilainya 0 , maka pendapatan asli daerah nilainya sebesar 17.754.

b. Koefisien regresi pajak hotel (b1) sebesar 0.275 menunjukkan arah positif, artinya jika pajak hotel mengalami kenaikan satu satuan, maka pendapatan asli daerah akan mengalami peningkatan sebesar 0.275 satuan. c. Koefisien regresi pajak reklame (b2) sebesar 0.220 menunjukkan arah negatif, artinya jika pajak reklame mengalami kenaikan satu satuan, maka pendapatan asli daerah akan mengalami kenaikan sebesar 0.220 satuan.

d. Koefisien regresi pajak parkir (b3) sebesar -0.123 menunjukkan arah negatif, artinya bahwa setiap kenaikan pajak parkir satu satuan maka variabel pendapatan asli daerah (Y) akan turun 1.123 dengan asumsi variabel bebas yang lain dari model regresi adalah tetap.

\subsection{Uji Hipotesis}

a. Uji t (Uji Parsial)

Tabel 4.8

Nilai uji t dan signifikan

\begin{tabular}{|c|c|c|}
\hline Variabel & $\mathrm{T}$ & sig \\
\hline X1 (Pajak Hotel) & 2.780 & .009 \\
\hline
\end{tabular}

1. Variabel Pajak Hotel (X1)

Variabel independen yang pertama yaitu pajak hotel (X1). Berdasarkan output Coefficients pada tabel di atas, diketahui bahwa nilai Sig sebesar 0.009. Nilai ini lebih

\begin{tabular}{|l|c|c|}
\hline $\begin{array}{l}\text { X2 (Pajak } \\
\text { Reklame) }\end{array}$ & .950 & .349 \\
\hline X3 (Pajak Parkir) & -.754 & .456 \\
\hline
\end{tabular}

Sumber data aplikasi SPSS 20.0

kecil dari 0.05 yang artinya secara parsial ada pengaruh signifikan antara variabel pajak hotel (X1) dengan variabel pendapatan daerah (Y).

2. Variabel Pajak Reklame (X2) 
Variabel independen yang kedua yaitu pajak reklame (X2). Nilai Sig yang terdapat pada tabel Coefficients adalah sebesar 0.349. Besaran nilai ini menunjukkan bahwa nilai Sig lebih besar dari 0.05. Artinya, variabel pajak reklame (X2) secara parsial tidak berpengaruh signifikan terhadap pendapatan asli daerah (Y).
3. Variabel Pajak Parkir (X3) Variabel independen yang kedua yaitu pajak parkir (X3). Nilai Sig yang terdapat pada tabel Coefficients adalah sebesar 0.456. Besaran nilai ini menunjukkan bahwa nilai Sig lebih besar dari 0.05 . Artinya, variabel pajak parkir (X3) secara parsial tidak berpengaruh signifikan terhadap pendapatan asli daerah (Y).

Sumber data aplikasi SPSS 20.0

b. Uji F (Simultan)

Tabel 4.9

Uji statistik F (simultan) dalam analisis regresi berganda digunakan untuk mengetahui apakah variabel independen (X) berpengaruh terhadap variabel dependen (Y) secara bersamasama. Dari hasil regresi menunjukkan bahwa nilai signifikasi 0.000 atau lebih kecil dari 0.05 sehingga dapat ditarik kesimpulan bahwa pajak hotel, pajak reklame dan pajak parkir secara bersama-sama berpengaruh positif dan signifikan terhadap pendapatan asli daerah.

\section{KESIMPULAN, KETERBATASAN DAN SARAN}

\subsection{Kesimpulan}

Secara parsial terdapat pengaruh positif dan signifikan pada variabel pajak hotel terhadap variabel pendapatan asli daerah. Variabel pajak reklame berpengaruh positif dan tidak signifikan terhadap pendapatan asli daerah. Sedangkan variabel pajak parkir berpengaruh negatif dan tidak signifikan terhadap pendapatan asli daerah. Secara simultan terdapat pengaruh signifikan pada variabel pajak hotel, pajak reklame dan pajak parkir terhadap pendapatan asli daerah.

\subsection{Keterbatasan Penelitian}

Keterbatasan penelitian adalah pada hasil penelitian. Berdasarkan data yang telah di olah, hasil penelitian dari dua variabel bertentangan dengan teori. Hal ini menjadi keterbatasan penelitian, oleh karena itu perlu adanya penelitian ulang mengenai kedua variabel tersebut.

\subsection{Saran}

Berdasarkan hasil temuan pada penelitian ini, berikut beberapa saran untuk pemerintah daerah Provinsi Jawa Tengah selaku objek penelitian serta untuk peneliti selanjutnya. 5.3.1 Bagi peneliti selajutnya 


Berdasarkan keterbatasan
penelitian, disarankan bagi
peneliti selanjutnya untuk
meneliti kembali variabel pajak
reklame dan pajak parkir
terhadap pendapatan asli daerah
karena masih terjadi
pertentangan teori pada
penelitian ini.

5.3.2 Bagi pemerintah daerah Provinsi Jawa Tengah

Pemerintah daerah hendaknya lebih menertibkan lagi pemungutan pajak reklame dan pajak parkir, karena dalam hal ini pajak reklame dan parkir dinilai masih banyak kurang tertib. Pemerintah daerah harus memperhatikan

manajemen pada bagian pengawasan pemasangan reklame dan mengontrol pertumbuhan $\triangle$ reklame. Memberikan sanksi tegas bagi para pemasang reklame yang tidak berizin dan tidak bayar pajak. Untuk masalah parkir, pemerintah daerah disarankan untuk menggunakan parkir elektronik agar mempermudah pembayaran parkir serta bisa mengontrol pajak parkir.
Halim, Abdul, 2007, Akuntansi dan Pengendalian Keuangan Daerah.Yogyakarta: Uppamp Ykpn

Korengkeng, Raymond R dkk. 2017. Analisis Potensi, Efektifitas, Efisiensi, Dan Kontribusi Pajak Reklame Terhadap Penerimaan Pajak Daerah Di Kabupaten Minahasa Utara . Fakultas Ekonomi dan Bisnis, Jurusan Akuntansi, Universitas Sam Ratulangi. Jurnal Riset Akuntansi Going Concern 12(1), , 210-219210
Mardiasmo,

Perpajakan, Yogyakarta: Andi

Offset, 2003

Mufidah, Asma, 2017. Analisis Pengaruh Pajak Parkir, Pajak Restoran Dan Retribusi Parkir Terhadap Pendapatan Asli Daerah Kota Malang (Studi Kasus Badan Pengelola Keuangan Dan Aset Daerah Kota Malang). Malang: E-Jurnal Riset Manajemen Universitas Islam Malang

\section{DAFTAR PUSTAKA}

Bastian, Indra. 2007. Sistem Akuntansi Sektor Publik. Edisi 2. Cetakan Kedua. Jakarta: Salemba Empat.

Darise, Nurlan. 2008. Akuntansi Keuangan Daerah (Akuntansi Sektor Publik). Cetakan Pertama. Jakarta: Indeks

Darize, Nurlan.2009, Pengelolaan Keuangan Daerah.Edisi 2.Indeks Jakarta,

Novalistia, Rizka Lutfita. 2016. Pengaruh Pajak Daerah, Retribusi Daerah, Lain-Lain Pendapatan Asli Daerah Yang Sah Dan Bagi Hasil Pajak Terhadap Tingkat Kemandirian Keuangan Daerah Pada Pemerintahan Kabupaten
Penerimaan Pajak Reklame, Pajak Hiburan, Pajak Hotel Dan Pajak Restoran Terhadap Pendapatan Asli Daerah Kota Yogyakarta Periode 2013-2015. Yogyakarta: E-journal Universitas PGRI Yogyakarta 


\begin{abstract}
Atau Kota Di Provinsi Jawa Tengah (Studi Empiris Pada Kabupaten / Kota Provinsi Jawa Tengah Periode 2012-2014). Jurusan Akuntansi, Fakultas Ekonomi, Universitas Pandanaran Semarang
\end{abstract}

Peraturan Pemerintah Republik Indonesia Nomor 58 Tahun 2005

Raperda Kota Semarang Nomor 16 Tahun 2016 Tentang Anggaran Pendapatan Dan Belanja Daerah Kota Semarang Tahun Anggaran 2017
Widodo Wahyu Indro dan Guritno Bambang, 2017. Pengaruh Pajak Hotel, Pajak Restauran Dan Pajak Hiburan Terhadap Pendapatan Asli Daerah (Pad) Di Kota Yogyakarta. Yogyakarta: Jurnal Visi Manajemen. Vol 2 No 22017

Wulandari, Phaureula Artha dan Emy Iryani, 2016. Analisis Pengaruh Kontribusi Pajak Daerah Terhadap Pendapatan Asli Daerah (Pad) Kota Banjarmasin. Banjarmasin: E-Journal Politeknik Negeri Banjarmasin

Apriani, Wahyu .2017. Analisis Pengaruh

Resmi, Siti .2009. Perpajakan:Teori dan Kasus, Jakarta:Salemba Empat.

Rizqiyah Iftakhur, 2014. Pengaruh Pajak Hotel, Pajak Restoran, Pajak Hiburan, Pajak Reklame Dan Pajak Parkir Terhadap Pendapatan Asli Daerah Kota Semarang(2009 Semarang
2013).
Penerimaan Pajak Daerah, Penerimaan Retribusi Daerah, Pendapatan Hasil Pengelolaan Kekayaan Daerah yang Dipisahkan, serta Penerimaan Lain-Lain Pendapatan Asli Daerah yang Sah Terhadap Pendapatan Asli Daerah Kota Salatiga Tahun Anggaran 20122016. Semarang: Universitas Pandanaran Semarang

Sanusi, Anwar. 2011. Metodologi ARA Fadillah, Laudy Justiar .2015. Kontribusi Penelitian Bisnis. Salemba dan Efektivitas Penerimaan Empat, Malang

Pajak Parkir pada Pendapatan Asli Daerah Kota Semarang Tahun 2005-2014 .Semarang :

Sugiyono. 2013. Metode Penelitian Kuantitatif, Kualitatif dan $R \& D$. Alfabeta, Bandung

Undang-Undang Republik Indonesia Nomor 23 Tahun 2014 Tentang Pemerintahan Daerah

Undang-Undang Republik Indonesia Nomor 28 Tahun 2009 Tentang Pajak Daerah dan Retribusi Daerah
Universitas Negeri Semarang

Asriyawati, Mutia Hendayani .2014. Pengaruh Pajak Hotel, Pajak Restoran Dan Pajak Reklame Terhadap Pendapatan Asli Daerah Kota Tanjungpinang Periode 2009-2013 . Jurusan Akuntansi Universitas Maritim Raja Ali Haji Tanjungpinang

Vamiagustin, Vadia dkk .2014. Pengaruh Pajak Daerah Terhadap Pendapatan Asli Daerah (Studi Kasus Pada Dinas Pendapatan 
Kota Batu Tahun 2010 - 2012) .

Badan Pusat Statistika Jawa Tengah, Malang : Jurnal Administrasi Bisnis (JAB)|Vol. 14 No. 2 September 2014 Publikasi 23 November 2017 https://jateng.bps.go.id/publicati on.html

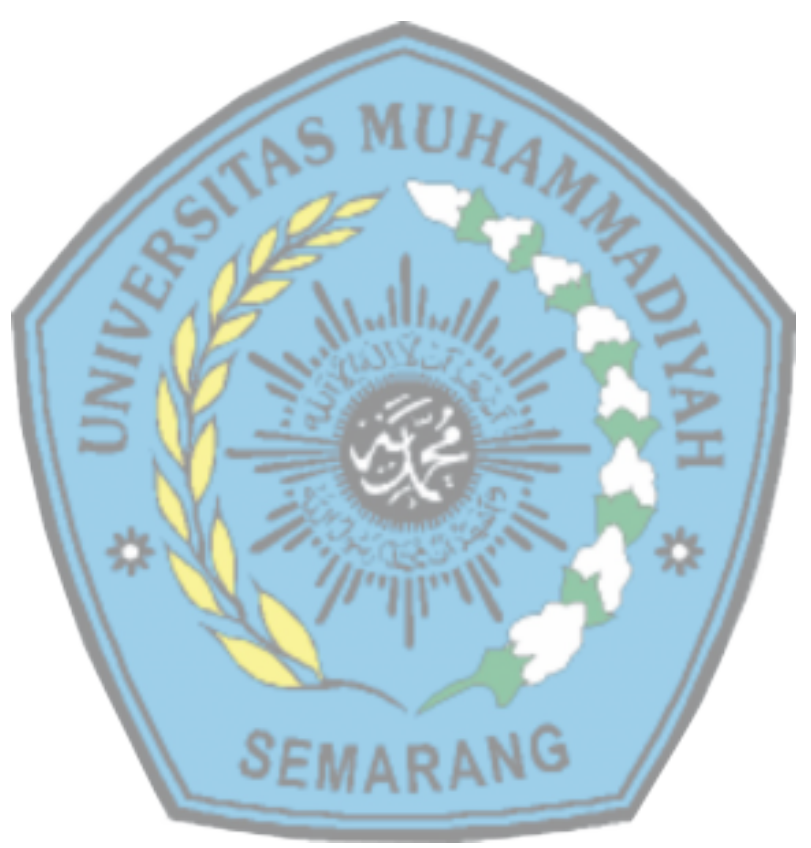

